\title{
Predicting Financial Vulnerability in Malaysia: Evidence From the Signals Approach
}

\author{
Tai-Hock Kuek ${ }^{1}$, Chin-Hong Puah $^{1} \&$ M. Affendy Arip ${ }^{1}$ \\ ${ }^{1}$ Faculty of Economics and Business, Universiti Malaysia Sarawak, Sarawak, Malaysia \\ Correspondence: Chin-Hong Puah, Faculty of Economics and Business, Universiti Malaysia Sarawak, Jalan Datuk \\ Mohammad Musa, 94300 Kota Samarahan, Sarawak, Malaysia. Tel: 60-12-657-0211.
}

Received: June 23, 2019

doi:10.5430/rwe.v10n3p89
Accepted: August 5, 2019

Online Published: September 26, 2019

URL: https://doi.org/10.5430/rwe.v10n3p89

\begin{abstract}
This paper aims to investigate Malaysia's vulnerability to a financial crisis. The methodology employed is an extension of the signals approach based on the original work of Kaminsky and Reinhart (1999). By studying the period from 2000M1 to 2016M9, we construct a financial vulnerability indicator (FVI) to measure the development of vulnerabilities in the Malaysian financial system. Our empirical findings unveil that the causes of crises are multidimensional. Notably, economic slowdown, decline in stock price and weak exports contain good predictive power in assessing financial vulnerability to a crisis. This study highlights the significance of internal and external macroeconomic conditions in determining a country's vulnerability.
\end{abstract}

Keywords: property market, financial crises, vulnerability indicator, signals approach

\section{Introduction}

Since the subprime mortgage crisis in 2008/2009, the International Monetary Fund (IMF) has led the way in creating an early warning system for crisis occurrence. Following that, interest in such warning mechanism has renewed, with the central banks of most developed nations being on the same track. Warning is provided by monitoring key indicators of specific economies to assist in forecasting financial crises as previous episodes of crises can shed light on the future financial and economic outlook. Nevertheless, the focus has been on developed nations where the root of the recent crises grew.

For developing nations like Malaysia, the recent property boom, particularly in residential properties, has raised concern about increasing household debt in the country as household loans are disproportional to the householders' means. The phenomenon is worsening when residential mortgage accounts the largest portion of most households' expenses (Borrowman et al. 2017). A report by Bank Negara Malaysia (2015) stated that the ratio of household debt to gross domestic product (GDP) hit 89.1 percent in 2015 (see Figure 1), its highest when comparing to other developing economies. Though the household debt-to-GDP ratio drops slightly to 88.4 percent in 2016, RAM Ratings' co-head of financial institution ratings Wong Yin Ching warned that the ratio would remain at the current level without a sustainable decline in the near term. 


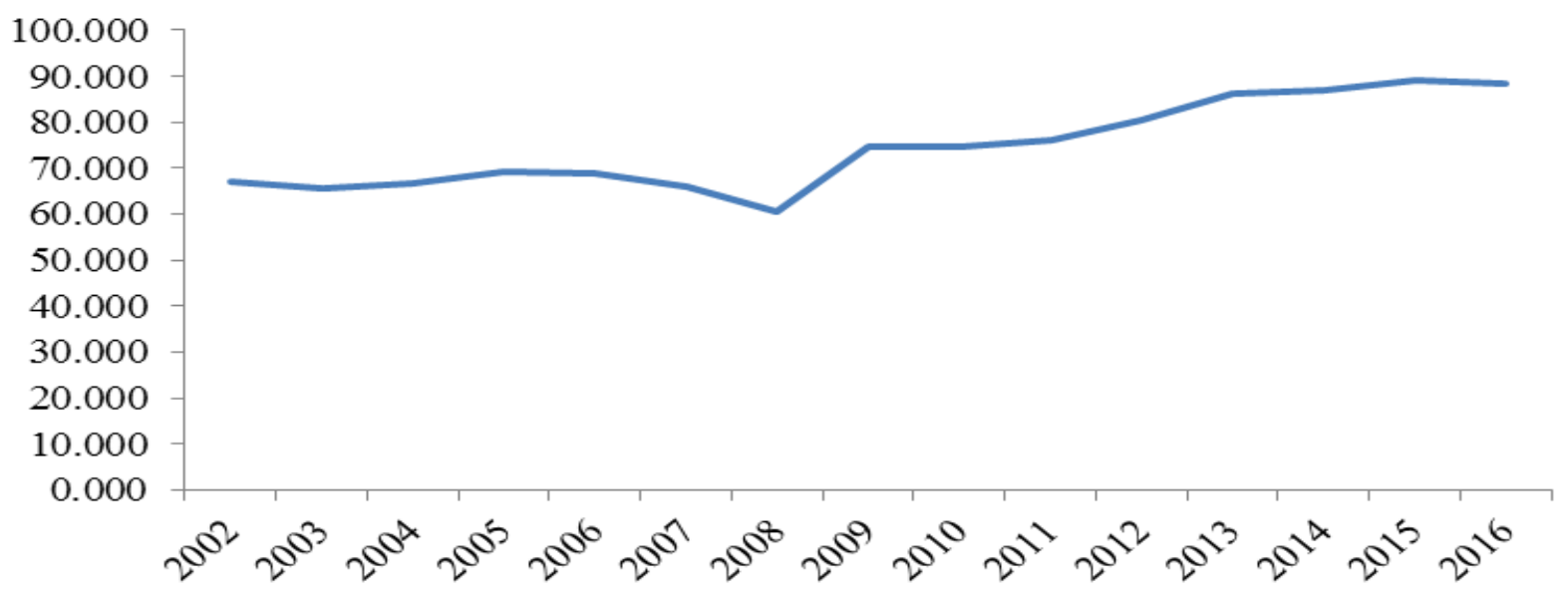

Figure 1. Household debt to GDP, 2002-2016

Source: Bank Negara Malaysia, various issues.

Currently, the huge gap between real GDP and loan amount has again raised concern about the sustainability of such gap as housing loans versus total loans have been accelerating from 10.9 percent in 2000 to 29 percent in 2015. As the government's initiative is to promote home ownership in Malaysia through various housing schemes, such move could worsen the current debt situation where households are tied to mortgages even as affordability and accessibility remain the key issues. Affordability is signified by household income, which is also a vital indication of property market demand (Hui and Gu 2009). Addition to that, boosting property demand tends to promote its price hike more than improve affordability (Ellis 2011). Though this circumstance would improve the book value of banking institutions, exposure to a more severe financial crisis is inevitable for the financial sector in the event of any property or asset bust.

Following the property price hike after 2010, Ahmad (2010) warned about the threatening property bubble in Malaysia, which was also a concern of some market players. Moreover, Mazlan (2014) feared that debt itself would turn out to be a platform for another financial crisis as loan amounts have outpaced GDP growth. This is backed by IMF (2012) research which stated that large household debt would lead to more severe downturns. In the event of excessive debt accumulation by households and property developers, a sharp downward adjustment in property prices or a sudden slump in the economic fundamentals are both likely to cause imbalances in banking institutions' balance sheets, resulting in the collapse of the financial market.

Based on the authors' best knowledge, it is essential for the Malaysian financial market to own and employ an early signalling mechanism to foretell its financial market outlook. This notion is not entirely new in the literature as such an innovative early warning system has been utilised for financial markets in developed economies. For instance, Huotari (2015) constructed a financial stress index for Finland, while Aboura and van Roye (2013) developed a real-time financial stress index for the French economy. Application of such early warning system in developing economies could fill the literature gap besides acting as a monitoring mechanism on the health of an economy. Therefore, this paper aims to construct a financial vulnerability indicator (FVI) with leading attributes for the Malaysian financial market.

The literature on early warning systems started to gain interest from researchers and practitioners in the 1990s. Kaminsky et al. (1998) and Kaminsky and Reinhart (1999) introduced an early warning mechanism based on the signals approach for vulnerability assessment towards twin crises. Kaminsky and Reinhart (1999) examined the link between currency and banking crises in a number of industrial and developing economies after the Mexican and Asian currency turmoil. They discovered that crises happen as the economy slows down after an economic boom which was driven by credit and capital inflows and accompanied by an overvalued currency.

Furthermore, Bruggemann and Linne (2002) extended the signals approach by developing a composite indicator of vulnerability of the Central and Eastern Europe countries. Bruggemann and Linne (2002) and Edison (2003) noted that an overvalued exchange rate, weak exports and deteriorating currency reserves perform well for crisis vulnerability examination. Edison (2003) and Ahec-sonje and Babic (2003) suggested that an early warning system could serve as a useful diagnostic tool to detect financial crisis; they developed a warning mechanism based on the 
signals approach for multiple economies and Croatia, respectively. With the exception of noting the importance of reserves by Edison (2003), Hsing (2004) identified the leading indicators of the Asian currency crisis using the weighted signals approach for seven economies from East Asia and found that the common leading indicators are net foreign capital flow, export, real exchange rate, consumer price index, production index and stock index. Meanwhile, Illing and Liu (2006) came out with an index of financial stress for the financial system in Canada.

As interest in early warning systems renewed in the wake of the subprime mortgage crisis in 2008/2009, more research emerged on warning systems related to financial crisis. For example, Duca and Peltonen (2011) constructed a financial stress index for the United States to measure macro-financial vulnerabilities by incorporating domestic and global perspectives. Similar to that of the findings by Bruggemann and Linne (2002) and Edison (2003), Frankel and Saravelos (2012) assessed the applicability of leading indicators to measure country vulnerability for multiple countries and discovered that the level of reserve appears to be a significant leading indicator. As conducted by Illing and Liu (2006), Pasricha et al. (2013) later also steered an assessment of financial system vulnerabilities in Canada using the signals approach by taking information from market intelligence into account.

Moreover, Karmarkar and Vani (2014), Feldkircher et al. (2014) as well as Christensen and Li (2014) developed an early warning signal system based on the signals approach with analysis of multiple countries. On the other hand, Hernandez et al. (2014) investigated fiscal stress in the euro area based on a country-specific signals approach. They showed that the performance of early warning systems can be enhanced using a country-specific approach, while Drehmann and Juselius (2014) employed the receiver operating characteristic (ROC) curve in developing early warning indicators of banking crises for 26 countries. Besides, Voon et al. (2016) and Puah et al. (2016) utilised the application of warning mechanism for the property cycle in Malaysia while Wong et al. (2016) and Soh et al. (2019) developed a system to deal with economic crises and tourism cycle, respectively. Additionally, Megersa and Cassimon (2015), Nguyen and Duy (2017), and Puah et al. (2017) developed an early warning system for Ethiopia, Vietnam, and Thailand, respectively, based on the signals approach. Megersa and Cassimon (2015) and Arip et al. (2019) noted the importance of local and international dynamics in their study.

\section{Method}

Financial vulnerability is defined as a higher probability of the occurrence of a stress-inducing situation on the future financial system, with the degree determined by the particular risk exposure. Detection on system imbalances is conducted to identify financial vulnerability through signalling future financial stress episodes. A high financial stress episode is considered a financial crisis. A financial crisis usually has a strong association with a significant change in credit volume and asset prices, severe disruption to the financial system in terms of intermediation and financing, serious issues with the balance sheet and government intervention (Claessens and Kose 2013). To benchmark financial vulnerabilities in Malaysia, the credit-to-GDP ratio is employed as the criterion to qualify as a crisis. Drehmann and Juselius (2014) pointed out the usefulness of the credit-to-GDP gap measure in crisis forecasting. For identification of crisis episodes, deviation of 1.25 times above the measure's mean is called a crisis for the period under study. The deviation is determined based on the accuracy of the crisis episodes identified.

Originally, Kaminsky and Reinhart (1999) introduced the signals approach as an early warning mechanism. It allowed the assessment of vulnerability towards currency and banking crises for an economy. The essential idea of the approach lies in behaviour changes in potential indicators during tranquil and crisis periods. The signals approach aims at identifying potential leading indicators which contain crisis information in terms of signals. A threshold value is determined based on the indicator's distribution to serve as a trigger for crisis once the threshold value is surpassed. Moreover, a crisis window must be defined for signals evaluation. In this paper, a crisis window of 12 months was selected as most of the macroeconomic and financial data available have relatively short series. Timing is used for a crisis window in previous studies, including Megersa and Cassimon (2015) and Nguyen and Duy (2017) with 12 month or 24 months, Bruggemann and Linne (2002) with 18 months and Kaminsky and Reinhart with 24 months.

Kaminsky and Reinhart (1999) assessed the effectiveness of stand-alone indicators where the signals are classified into four types of signal quality, as follows:

A: The number of months in which the indicator successfully emits a good signal

B: The number of months in which the indicator successfully emits a bad signal

$\mathrm{C}$ : The number of months in which the indicator does not successfully emit a good signal

D: The number of months in which no signal is detected

The classification of these four types of signals quality is illustrated in the following matrix: 


\begin{tabular}{lcc}
\hline & $\begin{array}{c}\text { Crisis } \\
\text { (within 12 months) }\end{array}$ & $\begin{array}{c}\text { No crisis } \\
\text { (within 12 months) }\end{array}$ \\
\hline Signal was detected & A & B \\
\hline No signal was detected & C & D \\
\hline
\end{tabular}

To determine the appropriate threshold value, different cut-off points are tested against individual indicators following Kaminsky and Reinhart (1999). The ranges of 5 percent to 35 percent and 65 percent to 95 percent are employed for the frequency distribution of individual indicators. The optimal threshold is chosen based on the minimization on the noise-to-signal ratio (NTS ratio) of individual indicators so as to select indicators containing more good signals. The NTS ratio, $\mathrm{w}_{\mathrm{j}}$, is defined as $\mathrm{w}_{\mathrm{j}}=(\mathrm{B} /((\mathrm{B}+\mathrm{D}))) /(\mathrm{A} /((\mathrm{A}+\mathrm{C})))$.

Most of the selected indicators contain good predictive power for vulnerabilities towards financial crises. To sum up, ten of the indicators have an NTS ratio smaller than 1 (see Figure 2). The best indicator is Real GDP with an NTS ratio of 0.21 , followed by the FTSE Stock Index with 0.23, Exports with 0.26, Total Reserve with 0.31, Housing Approvals with 0.33, Imports with 0.37, CPI and Real Effective Exchange Rate with 0.38, M2 with 0.62 and Loans and Advances with 0.89 .

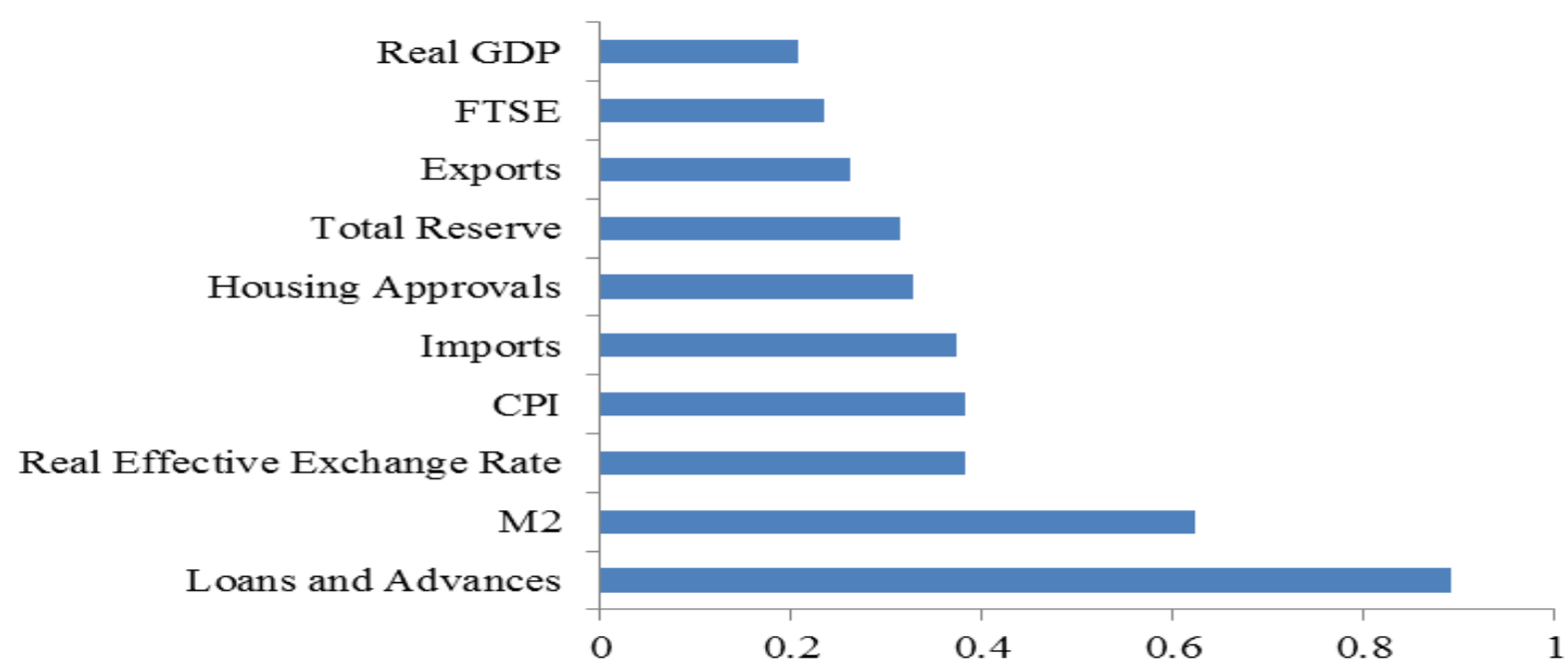

Figure 2. Noise-to-signal ratio of indicators

In general, a country's vulnerability to a crisis can be determined by more emitted signals from the indicators. However, determination based on signals alone might be insufficient as essential insights may be lost. Hence, construction of a composite indicator by compiling the individual indicators is advantageous in this case. For indicator construction, this paper follows Bruggemann and Linne (2002). They considered the strength of the signal, the timing of the signal and prognostic quality of an indicator in composite indicator construction.

First, the strength of the signal is differentiated by introducing a second threshold which is equivalent to half the original percentile of the frequency distribution. From that, an indicator exceeding the second threshold will be double weighted while an indicator will be single weighted only if it does not surpass the second threshold. In addition, an indicator that does not even surpass the first threshold will be zero weighted. Thus, three possible outcomes exist at any point in time:

$$
I_{t}^{j}=\left\{\begin{array}{ll}
0 & I_{t}^{j}<T_{1}^{j} \\
1 \text { for } & T_{1}^{j} \leq I_{t}^{j}<T_{2}^{j} \\
2 & I_{t}^{j} \geq T_{2}^{j}
\end{array} \quad j=1_{s, n} k x\right.
$$


where $\mathrm{k}$ is the number of indicators and $\mathrm{t}$ is the time index. $\mathrm{T}^{\mathrm{j}}{ }_{1}$ and $\mathrm{T}_{2}^{\mathrm{j}}$ symbolize the first and second threshold while $\mathrm{I}_{\mathrm{t}}^{\mathrm{j}}$ is the value of the indicator.

Second, timing of the signal is taken into account as it is crucial in determining a country's vulnerability to a crisis. Timing comes with an assumption that recent signals are relatively more important for the current crisis potential than past signals where a moving 12-month window is constructed with a geometric weighting scheme:

$$
Z_{t}^{j}=\sum_{i=1}^{12} \frac{l_{t+1-i}^{j}}{i} \quad \text { for } t \geq 12
$$

Third, the prognostic quality of the indicators plays an important role in indicator construction. Higher weights are assigned to indicators with good predictive ability by means of a good signal through inversing their respective NTS ratio. Thus, the FVI can be combined using the following formula:

$$
F V I_{t}=\sum_{j=1}^{k} \frac{Z_{t}^{j}}{w^{j}}
$$

Finally, the conditional probabilities are calculated for the crisis occurrence. For this purpose, these conditional probabilities are applied to draw conclusions about the probability of a crisis happening as the composite indicators only provide forewarnings about a country's vulnerability to financial crisis. The calculation of the conditional probabilities is as follows, as Edison (2003) suggested:

$$
\operatorname{Pr}\left[\text { crisis }_{t_{t, t} t+12} \mid F V I_{1} \leq F V I_{\mathrm{t}}<F V I_{u}\right]=\frac{\sum \text { No. of months for } F V I_{1} \leq F V I_{\mathrm{t}}<F V I_{u} \text { and crisis happens }}{\sum \text { No. of months for } F V I_{1} \leq F V I_{\mathrm{t}}<F V I_{u}}
$$

where crisis $_{\mathrm{t}, t+12}$ is the crisis occurrence within 12 months given that the FVI falls in the interval between its upper $\left(\mathrm{FVI}_{\mathrm{u}}\right)$ and lower boundary $\left(\mathrm{FVI}_{\mathrm{l}}\right)$.

In this paper, higher frequency data on a monthly basis are utilised for better accuracy of indicator development. The period under study spanned from 2000M1 to 2016M9 for predicting financial vulnerabilities in Malaysia. The constructed indicator was inclusive of financial and macroeconomic variables, including monetary aggregate M2, real effective exchange rate, total reserve, exports, housing approvals, consumer price index, imports, loans and advances, Malaysian Financial Times Stock Exchange (FTSE) index and real GDP. For the benchmark, the variable of credit-to-GDP ratio is selected to proxy a country's financial vulnerability. Real GDP is obtained by dividing GDP by the consumer price index. Both GDP and the credit-to-GDP ratio are interpolated as the data were taken on a quarterly basis using Gandolfo (1981) and Chow-Lin interpolation (1971), respectively. All of the data were obtained from the CEIC Database and Bank for International Settlements.

\section{Results}

Before proceeding with the construction of FVI, ten potential indicators with an NTS ratio of less than 1.0 are selected as the indicators with leading attributes. The ten individual indicators are selected from the real sector indicator (Real GDP, FTSE, Housing Approvals and CPI), external sector indicator (Exports, Imports and Real Effective Exchange Rate), financial sector indicator (M2 and Loan and Advances) and capital account indicator (Total Reserve). The risk tails and justifications for each leading indicator are presented in Table 1. For the average lead time of indicators where the first signal of a crisis is detected, the top three indicators with the highest lead time are FTSE (10.67 months in advance), Housing Approvals (10.33 months in advance) and Exports (9 months in advance).

As the selection of leading indicators is completed, the ten individual indicators are compiled into a single composite indicator, the financial vulnerability index, using the procedure suggested by Bruggemann and Linne (2002). The vulnerability to financial crisis increases with the uptrends in the indicator itself. The graphical illustration of FVI and credit-to-GDP ratio is presented in Figure 3. The constructed indicator successfully traces three major financial episodes under the period of study between 2000M1 and 2016M9. The three major financial episodes included the dotcom bubble in 2001, subprime mortgage crisis in 2008-2009 and property cooling in Malaysia in 2015-2016. 
Table 1. Risk tail and justification on selected indicators

\begin{tabular}{|c|c|c|}
\hline Leading Indicator & Risk Tail & Comments \\
\hline \multicolumn{3}{|l|}{ Real Sector } \\
\hline Real GDP & Lower Tail & $\begin{array}{l}\text { Economic recession often precedes crises. Crisis vulnerability } \\
\text { of an economy increases as economic growth slows down. }\end{array}$ \\
\hline FTSE & Lower Tail & Downturns in stock market are linked with crises. \\
\hline Housing Approvals & Lower Tail & $\begin{array}{l}\text { Property sector plays a huge part in the whole economy where } \\
\text { it is associated closely to economic development. Low housing } \\
\text { approvals indicate slowdown in economic growth. }\end{array}$ \\
\hline CPI & Upper Tail & $\begin{array}{l}\text { High inflationary pressure negatively affects the financial } \\
\text { sector through various channels and it may proxy for } \\
\text { misalignments at the macroeconomic level. }\end{array}$ \\
\hline \multicolumn{3}{|l|}{ External Sector } \\
\hline Exports & Lower Tail & $\begin{array}{l}\text { Weak exports reduce a country's income from foreign } \\
\text { exchange trading for public financing. }\end{array}$ \\
\hline Imports & Upper Tail & $\begin{array}{l}\text { Rising imports are symptoms of an overvalued exchange rate, } \\
\text { which also signals a loss of competitiveness. }\end{array}$ \\
\hline $\begin{array}{l}\text { Real Effective Exchange } \\
\text { Rate }\end{array}$ & Lower Tail & $\begin{array}{l}\text { Overvaluation of exchange rates is a driving force to potential } \\
\text { crisis build-up. }\end{array}$ \\
\hline \multicolumn{3}{|l|}{ Financial Sector } \\
\hline M2 & Upper Tail & Expansionary monetary policy is related to the onset of a crisis. \\
\hline Loans and Advances & Upper Tail & $\begin{array}{l}\text { Rapid credit expansion exposes the financial system to risk of } \\
\text { balance sheet imbalance. }\end{array}$ \\
\hline \multicolumn{3}{|l|}{ Capital Account } \\
\hline Total Reserve & Lower Tail & $\begin{array}{l}\text { A country's total reserve provides a cushion for financial or } \\
\text { economic shocks. }\end{array}$ \\
\hline
\end{tabular}




\section{FVI}

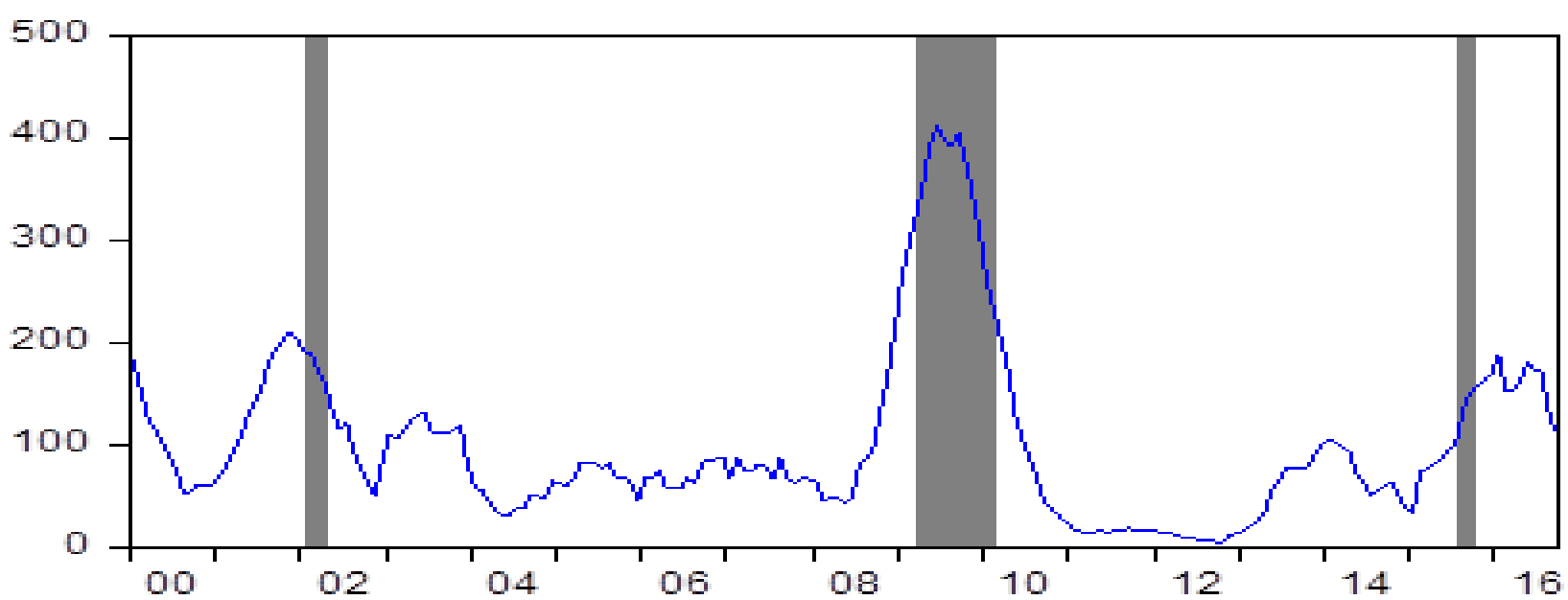

CGDP

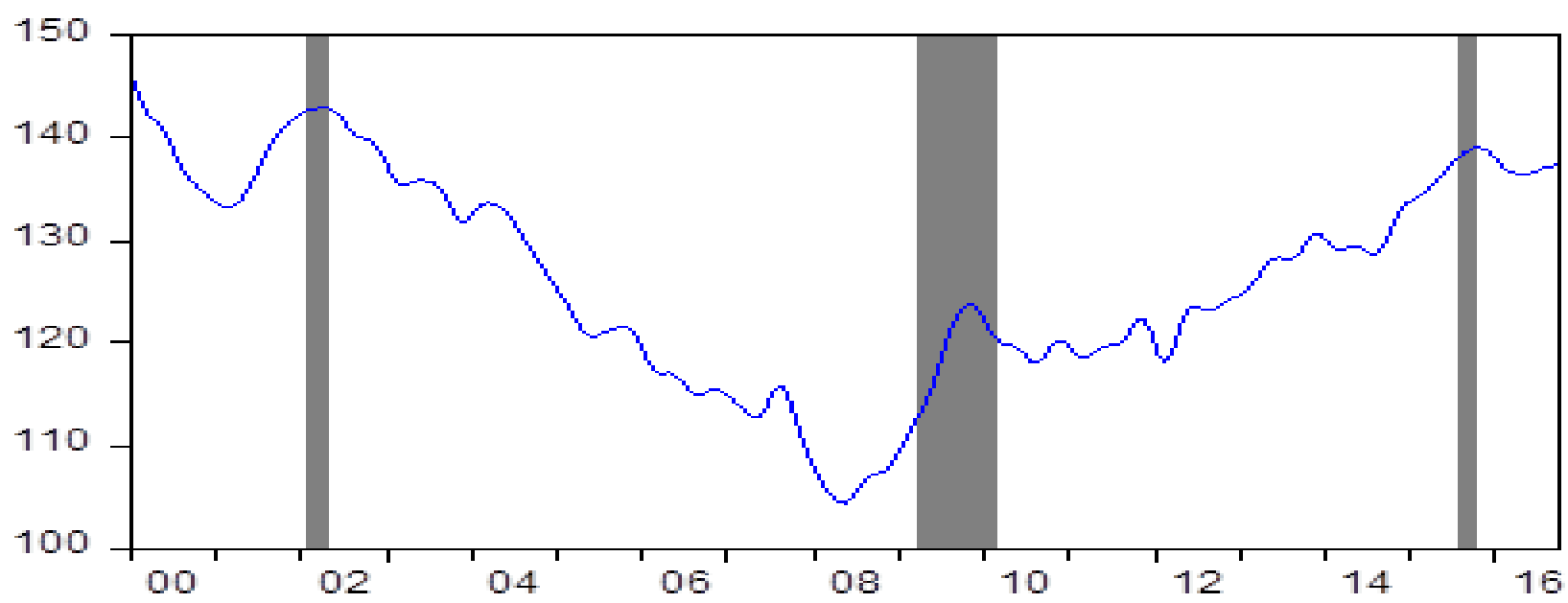

Figure 3. Graphs of FVI and CGDP, 2000M1-2016M9

Table 2 shows the conditional probabilities of a financial crisis based on the constructed FVI. For a wide range of values of the FVI, the probability of a crisis occurrence increases alongside the increment in the indicator. For the indicator penetrating through the value of 175 and above, the probability of a crisis occurrence could reach 81.48 percent while the unconditional probability is recorded at only 14.36 percent.

Table 2. Conditional probabilities of a financial crisis

\begin{tabular}{cc}
\hline Financial Vulnerability Indicator & Probability of a Crisis (\%) \\
\hline $0-35$ & 0 \\
\hline $36-70$ & 16.07 \\
\hline $71-105$ & 23.91 \\
\hline $106-140$ & 16.00 \\
\hline $141-175$ & 40.00 \\
\hline$>175$ & 81.48 \\
\hline Unconditional Probability: $14.36 \%$ &
\end{tabular}




\section{Discussion}

This paper aims to investigate Malaysia's vulnerability to a financial crisis. The paper demonstrates the effectiveness of the signals approach in predicting financial vulnerabilities. Acting as an early warning mechanism, the signals approach can identify the leading indicators of financial vulnerabilities in an economy where those indicators are useful in signalling imminent crisis in advance. Importantly, with the monitoring of individual indicators, an indication of trouble in the economy can be identified and suitable policy implemented to tackle the misalignments. Therefore, it is vital to utilise the signals approach as a forecasting tool for a country's strategic policies.

Based on the empirical findings, various insights from relevant indicators containing predictive power of a country's vulnerability can be distinguished. For the case of Malaysia, we discovered that the common triggers of a crisis were economic slowdown, decline in stock price and weak exports where they are the fundamental drivers of the economy. A decline in stock price and weak exports indicate poor business sentiment as companies are low in profitability, which in turn triggers an economic slowdown as a whole. For the performance of leading indicators, stock price, housing approvals and exports were indicators with good leading attributes for crisis signalling. Based on both empirical analyses, they highlight the significance of internal and external macroeconomic conditions in determining a country's vulnerability.

Two recommendations can be offered for policymaking based on the empirical outcomes. First, the attractiveness of exports through exchange rate policy helps to protect a country from vulnerability. As overvaluation of the exchange rate is a driving force of potential crisis build-up, the crucial aspect of the exchange rate policy is to prevent high appreciation of the real exchange rate. This can ensure that the domestic goods and services remain competitive in international markets and exports earnings can boost the country's economic growth.

Second, the financial market conditions can be enhanced through investment policy to provide an attractive investment environment. Foreign direct investment (FDI) is a major catalyst to economic development and, needless to say, income growth and employment. Liberalisation of FDI regimes and implementation of other policies are vital to attract investment. Monitoring the mobilisation of investment resources has to go deeper so as to protect the interests of foreign investors and boost their investing confidence with the host country. At the same time, the domestic economy can also maximise the benefits of a foreign presence through its investment activities.

Finally, though an early warning system is useful as a forecasting tool for crisis occurrence, certain limitations to any such mechanism are still undeniable. Not all the issues that have a potential impact on a country's economy have been taken into account in the warning system, such as the institutional nature and natural disasters, which may be informative for a certain country at a particular time only. Moreover, further research with available data of higher frequency can also be useful in producing better findings for policy decisions.

\section{Acknowledgements}

Financial support from Universiti Malaysia Sarawak (UNIMAS) and Fundamental Research Grant Scheme [F01/FRGS/1493/2016] are gratefully acknowledged.

\section{References}

Aboura, S., \& van Roye, B. (2013). Financial stress and economic dynamics: an application to France. Kiel Institute for the World Economy, Working Paper Series No. 1834.

Ahec-sonje, A., \& Babic, A. (2003). Measuring and predicting currency disturbances: the "signals" approach. Ekonomski Pregled, 54(1-2), 3-37. https://doi.org/336.711.6(497.5)

Ahmad, D. (2010, Novermber 26). Of property overhang and mounting household debt. Malaysia Today. Retrieved from http://www.malaysia-today.net/of-property-overhang-and-mounting-household-debt/

Arip, M. A., Kuek, T. H., \& Puah, C. H. (2019, in press). Forecasting financial vulnerability in Malaysia: a non-parametric indicator approach. Asian Journal of Business Research.

Bank Negara Malaysia. (2015). Financial Stability and Payment Systems Report 2015. Kuala Lumpur: Bank Negara Malaysia, Malaysia.

Borrowman, L., Kazakevitch, G., \& Frost, L. (2017). How long do households remain in housing affordability stress? Housing Studies, 32(7), 1-18. https://doi.org/10.1080/02673037.2017.1280140

Bruggemann, A., \& Linne, T. (2002). Are the central and Eastern European transition countries still vulnerable to a financial crisis? Results from the signals approach. IWH Discussion Papers, No. 157.

Chow, G. C., \& Lin, A. (1971). Best linear unbiased interpolation, distribution, and extrapolation of time series by 
related series. The Review of Economics and Statistics, 53(4), 372-375.

Christensen, I., \& Li, F. (2014). Predicting financial stress events: a signal extraction approach. Bank of Canada, Working Paper, No. 37.

Claessens, S., \& Kose, M. A. (2013). Financial crises: explanations, types, and implications. International Monetary Fund, IMF Working Paper, No. 28.

Drehmann, M., \& Juselius, M. (2014). Improving EWIs for banking crises - satisfying policy requirements. International Journal of Forecasting, 30(3), 759-780.

Duca, M. L., \& Peltonen, T. A. (2011). Macro-financial vulnerabilities and future financial stress. European Central Bank, Working Paper Series No. 1311.

Edison, H. J. (2003). Do indicators of financial crises work? An evaluation of an early warning system. International Journal of Finance and Economics, 8, 11-53. https://doi.org/10.1002/ijfe.197

Ellis, L. (2011). Eight policy lessons from the US housing meltdown. Housing Studies, 26(7-8), 1215-1230. https://doi.org/10.1080/02673037.2011.615145

Feldkircher, M., Gruber, T., \& Moder, I. (2014). Using a threshold approach to flag vulnerabilities in CESEE economies. National Bank of Austria, Foreign Research Division, 3, 8-30.

Frankel, J. A., \& Saravelos, G. (2012). Can leading indicators assess country vulnerability? Evidence from the 2008-09 global financial crisis. Journal of International Economics, 87, 216-231. https://doi.org/10.2139/ssrn.1971286

Gandolfo, G. (1981). Qualitative analysis and econometric estimation of continuous time dynamic models. Amsterdam, Netherlands: North Holland- Publishing Company.

Hernandez, P. C., Moral-Benito, E., Koester, G. B., \& Nickel, C. (2014). Signalling fiscal stress in the Euro area: a country-specific early warning system. Bank of Spain, Working Paper Series, No. 1418.

Hsing, H. M. (2004). Leading indicators of Asian currency crisis - the weighted signal approach. Asia Pacific Management Review, 9(1), 119-136. https://doi.org/10.6126/APMR.2004.9.1.06

Hui E. C. M., \& Gu, Q. (2009). Study of Guangzhou house price bubble based on state-space model. International $\begin{array}{lllll}\text { Journal of Strategic Property } & \text { Management, } & \text { 13(4), }\end{array}$ https://doi.org/10.3846/1648-715X.2009.13.287-298

Huotari, J. (2015). Measuring financial stress - a country specific stress index for Finland. Bank of Finland, Research Discussion Paper No. 7.

Illing, M., \& Liu, Y. (2006). Measuring financial stress in a developed country: an application to Canada. Journal of Financial Stability, 2, 243-265.

International Monetary Fund. (2012). Dealing with household debt. World Economic Outlook: Growth Resuming, Dangers Remain (April 2012). Washington, D.C.: International Monetary Fund.

Kaminsky, G. L., \& Reinhart, C. M. (1999). The twin crises: the causes of banking and balance-of-payments problems. The American Economic Review, 89(3), 473-500. https://doi.org/10.1257/aer.89.3.473

Kaminsky, G. L., Lizondo, S., \& Reinhart, C. M. (1998). Leading indicators of currency crisis. IMF Staff Papers No.45, 1-48.

Karmarkar, Y., \& Vani, S. (2014). Early warning signal system for economic crisis: a threshold and indicators approach. Pacific Business Review International, 6(8), 60-70.

Mazlan, N. (2014, March 12). An investigation on household debt in Malaysia. International Centre for Education in Islamic Finance. Retrieved from http://www.inceif.org/research-bulletin/investigation-household-debt-malaysia/

Megersa, K., \& Cassimon, D. (2015). Assessing indicators of currency crisis in Ethiopia: signals approach. African Development Review, 27(3), 315-330. https://doi.org/10.1111/1467-8268.12148

Nguyen, T., \& Duy, N. N. (2017). Developing an early warning system for financial crises in Vietnam. Asian Economic and Financial Review, 7(4), 413-430. https://doi.org/10.18488/journal.aefr/2017.7.4/102.4.413.430

Pasricha, G., Roberts, T., Christensen, I., \& Howell, B. (2013). Assessing financial system vulnerabilities: an early warning approach. Bank of Canada Review, Autumn 2013, 10-19. 
Puah, C. H., Kuek, T. H., Arip, M. A., \& Wong, S. S. L. (2016). Forecasting property market dynamics: insights from the property cycle indicator. INFORMATION, 19(6(B)), 2225-2232. https://doi.org/10.18374/JABE-15-2.1

Puah, C. H., Kuek, T. H., \& Arip, M. A. (2017). Assessing Thailand's financial vulnerability: an early warning approach. Business and Economic Horizons, 13(4), 496-505. http://dx.doi.org/10.15208/beh.2017.34

Soh, A. N., Puah, C. H., Arip, M. A., \& Kuek, T. H. (2019, in press). Oil price and tourism cycle: a Markov regime-switching model. International Journal of Energy Economics and Policy.

Voon, Z. C., Puah, C. H., \& Wong, S. S. L. (2016). Housing market dynamics: new insights from the indicator approach. Journal of Economics and Economic Education, 17(3), 1-8.

Wong, S. S. L., Puah, C. H., Abu Mansor, S., \& Liew, V. K. S. (2016). Measuring business cycle fluctuations: an alternative precursor to economic crises. Economic Computation and Economic Cybernetics Studies and Research, 50(4), 235-248. 